Linguistik Terapan 18 (1) (2021): 68 - 78

Jurnal Linguistik Terapan Pascasarjana

Available online

http://jurnal.unimed.ac.id/2019/index.php/JLT-Unimed

\title{
INTERACTION BETWEEN DUAL TEACHING MEDIA AND MOTIVATION ON THE STUDENTS' LISTENING ACHIEVEMENT
}

\author{
Wiwin Pratiwi Harsa \\ Amrin Saragih \\ Rahmad Husein
}

\author{
English Applied Linguistic Program \\ Postgraduate Program - Universitas Negeri Medan
}

Diterima Desember 2020; Disetujui Februari 2021; Dipublikasikan April 2021

\begin{abstract}
The objectives of this study are to describe the interaction between the results of teaching by audio visual and audio teaching media, and motivation towards the students' listening. The research design was experimental research by using factorial design $2 \times 2$. There were 64 students from grade eighth in 2020/2021 academic year of SMP Al Washliyah 8 Medan as sample of this research. The students were divided into two groups. The first group was treated by using audio visual media and the second group was treated by using audio media. The motivation test was conducted for classifying the students upon the high and low motivation by using questionnaire. Students' achievement in listening was measured by using multiple choice tests. The data were analyzed by applying Two-ways ANOVA, the results revealed that students' listening achievement taught by using audio visual media significantly higher than that taught by using audio media and students' listening achievement with high motivation was higher than students with low motivation. There was significant interaction between dual teaching media and motivation on the students' listening achievement with $\mathrm{F}_{\text {observed }}$ is lower than $\mathrm{F}_{\text {table }}$ at the level significance $\alpha=0.05\left(\mathrm{~F}_{\mathrm{obs}}=1.76<\mathrm{F}_{\mathrm{tab}}=2.81\right)$ however, the value of significant level is $\alpha=0.19$ higher than 0.05 . Thus, both teaching media and motivation significantly affect the students' listening achievement.
\end{abstract}

Keywords: Teaching Listening, Audio Visual Media, Audio Media, Motivation, Listening Achievement.

How to Cite: Pratiwi Harsa, Wiwin. (2021). Interaction between Dual Teaching Media and Motivation on The Students' Listening Achievement. Jurnal Linguistik TerapanPascasarjana Unimed. 18(1): 68 - 78

ISSN: 2407 - 7410 


\section{INTRODUCTION}

Listening is the basis for the development of all other skills and the main channel through which the student makes initial contact with the target language and its culture (Kurniawati, 2016). Through active listening, students acquire vocabulary and syntax, as well as better pronunciation, accent and intonation. Though listening skill is very important, for some language learners it is considered to be the most difficult language skill.

Some problems appear in many EFL learners when they have limited vocabulary. They cannot understand what the speaker says. Listeners sometimes fail to realize that the speaker had moved to other topic since it is a foreign language. Since listening is the process of receiving information, the listener needs to concentrate to get the point of what speaker says. Those difficulties exist for foreign language speaker especially new learner. Moreover, the difficulties of English listening usually happen because of certain problems such as the pronunciation of some English words is changing when it combined with other words (Wilson, 2008). From the linguistics point, he argues that the lack of vocabulary and complex grammatical structure also become problems.

The preliminary class observation has been conducted at SMP Al Wasliyah 8 Medan and concerned about the poor results of teaching listening to Junior High School students, particularly to second grade (year 8) students about descriptive text. By interviewing the class teacher, it was known that the students' listening achievement is low because cannot fulfill the minimum passing grade on the topic of descriptive text $(\mathrm{KKM}) \geq 70$. As the input, students must gain the score as the achievement around $70 \%$ up to $80 \%$.

From the observation, in English teaching process the writer still found some serious problems on it like the text book that often used by the teacher at the school is not completed by audio file and the teacher still uses conventional tool in teaching listening orally.

Students with high motivation will be easier to understand the material given than the students with low motivation. However, even if they have high motivation in learning, only few students can reach standard based score particularly in descriptive topic, while the remaining students still cannot fulfill the standard competency based in listening comprehension. Some of them feel confused to understand the text and some unfamiliar vocabularies.

Based on the data from the teacher, there are 22 students gain score $<70 \%$. Thus, there are 10 students who are able to get the score $>70 \%$ from the total of students in one class. The 
mean score of students' listening achievement on the topic of descriptive text at SMP AlWashliyah 8 Medan can be seen in the following table:

Table 1. Students' Listening Comprehension Score

\begin{tabular}{cc}
\hline Class & Average Score of Students \\
\hline XA & 69 \\
\hline XB & 67 \\
\hline Average Score & 68 \\
\hline (Source: Mark Collection List (Daftar Kumpulan Nilai: DKN) of SMP Al Wasliyah 8 Medan, School
\end{tabular}
Year of 2019/2020)

The use of media in teaching learning process can help teachers to create learning situation effectively. Many media and many styles of visual presentation are useful to the language learner (Susilana, 2007). That is to say, audio-visual materials have positive contributions to language learning as long as they are used at the right time, in the right place. In this respect, audio-visual media like videos provide important learning opportunities to students practice in a second language.

Multimedia as audio visual media teaching material is necessary for students to improve their learning activities on subject of listening comprehension (Pangaribuan, Sinaga and Sipayung, 2017). Meanwhile, using authentic videos as audio-visual media is better than using audio compact disc as audio media in teaching listening comprehension (Rismawati, 2017). Video as audio-visual media teaching material is an effective media in teaching listening comprehension (Mahadi, Yana and Haerun, 2018).

Based on the problems above, the use of animation video on the topic of descriptive text as audio-visual media will be applied in order to increase the students' ability in listening comprehension. The animation video provides one of the stories of descriptive text with colorful images, moving pictures and script. The animation video is one of audio-visual media in listening comprehension to help increasing students' attention, so they can be motivated to learn. By watching animation video, students will be interest to learn and comprehend descriptive text, it is expected that they can have a good understanding in learning process.

Considering this condition, it is of interest to study and describe the interaction between the results of teaching listening class by using audio visual media and audio media 
and student's motivation in order to improve their listening achievement in learning English. In the line with explanation above, this study is devoted to describe the method with on entitle Interaction between Dual Teaching Media and Motivation on the Student's Listening Achievement.

\section{The Concept of Listening}

Listening is the activity of paying attention to and trying to get meaning from something we hear (Underwood, 1989). Listening is a working method of comprehension and constructing meaning from both verbal and non-verbal texts (Nunan, 1999). Listening, in its broadest sense, as a process of receiving, what the speaker actually says; constructing and representing meaning; negotiating meaning with the speaker and responding; and creating meaning through involvement, imagination and empathy (Rost, 2011). Another, listening is the route to tolerate, make meaning out of, and offer clarification as nonverbal messages to be spoken (Purdy, 1997).

\section{The Listening Comprehension}

Listening comprehension requires a desire to understand another human being, an attitude and respect and acceptance, and willingness to open one's mind to try and see things from another's point of view. It requires a high level of concentration and energy. It demands that we set aside our own thoughts and agendas, put ourselves in another's shoes and try to see the world through that person's eyes (Ulum, 2015). Listening comprehension is the various processes of understanding and making sense of spoken language. This involve knowing speech sounds, comprehending meaning of individual words and understanding the syntax of sentences (Gilakjani and Sabouri, 2016).

\section{The Listening Process}

Listening is an active process in which the listener must discriminate amongst sounds, understand words and verbal structures, interpret intonations and retain the information gathered in order to interpret it in the context or setting (Underwood, 1989). Listening is not automatic but to be better listeners we need to understand and work with the components of the listening process (Purdy, 1997). Contrary to what everybody thinks about foreign language learning, listening competence is wider than speaking competence. This is a reason why; recently, the language teaching profession has brought into focus on listening 
comprehension. Listening process is divided into three stages: pre-listening, in-while listening and post-listening (Wilson, 2008).

\section{Descriptive Text}

Descriptive text is a text provides information on a topic through descriptive facts, details, characteristics and traits (Murphy, 2003). We use descriptive text to say what something or somebody is pictures with words, and we can describe a person, animals, plants, places, process, thoughts or feelings. So, it can be concluded that a descriptive text is a text which says what a person or a thing is like. Its purpose to describe and reveal a particular person, place or thing. Generic structure elements of descriptive text are identification and description (Knapp and Watkins, 2005). Then, the language features are focused on specific participant and using simple present tense.

\section{Teaching Listening Comprehension}

The aim of teaching listening comprehension is to help students with listening in their real lives, but there is a large variety of different types of listening in real life, such as listening to announcements in stations, airports and so on, listening to the radio, participating in a conversation face-to-face, watching television, participating in a meeting, seminar or discussion, taking part in a lesson, participating in a telephone conversation, among others.

Students, as listeners, should be made aware not every clue, in this case word, is equally important to the message. Therefore, when they miss a piece of language, they need not panic since there is a good chance that other clues will enable them to understand the message. The criterion of success in listening comprehension is not whether he/she (student, as a listener) has understood every word, but whether he/she has constructed enough of the meanings in order to satisfy his/her own communicative purposes (Littlewood, 1998). Students can find various ways that can be done usefully by them to do something. Activities are important for students in learning, because this is a part of learning process. it means that if the students can pay attention in their learning activities, they will improve their awareness and processing their listening comprehension.

\section{The Teaching Media}

The purpose of teaching media is to facilitate communication in learning process. Media as something that can be used to channel messages from senders to recipients so that they can stimulate students' thoughts, feelings, attention and motivation and attention so that 
the learning process takes place (Sadiman, 2009). Also, media can be interpreted everything that is used to convey message and can stimulate thoughts, feelings, attention, and willingness to learn so that it can encourage deliberate learning, have goals and control (Miarso, 2004).

The use of audio-visual media in language teaching has gained much importance nowadays. Audio-visual is described as an electronic picture series with audio component and so is drawn image component presented by video tape and they are played by a video player (Anderson and Lynch, 1998).

Video animation as an audio-visual media that produces a moving image and natural or adjusted sound. Animated video as teaching media is able to present/display objects that are difficult to be taken directly to the classroom. Animated video lesson will greatly assist students in mimic, follow, imitate and understand the sequence of actions that must be mastered a lesson.

Audio media is used to involve the sense of hearing so that the process of listening occurred. While another expert states that audio learning media if it is used properly can contribute to education (Nation and Newton, 2009). With audio, students can listen to different accent variations of more than one speaker. Also, it can sharpen their sensitivity to hear what the speaker says even in different accent.

\section{Students' Motivation in Learning}

Motivation is considered significant in its role in language learning success. Along this line of thoughts, student's motivation toward English language learning can, to a certain degree, influence their learning results. It is worth investigating how student become successful or failed in learning English because it might affect their motivation and the way they learn the language. Dornyei (2002) stated that the learner's enthusiasm, commitment and persistence are the key determinant of success or failure. Learning and motivation have the same importance in order to achieve something. Learning makes us gain new knowledge and skills and motivation pushes us or encourage us to go through the learning process.

Brophy (2013) classified the student's motivation in learning into four aspects. They are attention in learning, motivation as learning desire, willingness and enjoyment in the process of learning. In this case, the study just focuses on the students' high and low motivation that influence their English language learning especially in listening comprehension. 


\section{METHODOLOGY}

In this research, experimental design by using factorial design $2 \times 2$ ways used. A factorial design used in which two or more variables were manipulated simultaneously in order to study the independent effect of each variable on the dependent variable as well as the effect due to the interaction among the several variables (Ary, 2010). The pretest and posttest were given to investigate the effect of teaching media on student's listening achievements. The subject of the study was sixty-four the second grade of SMP AlWashliyah 8 Medan in academic year of 2020/2021. In this research, pre-test and post-test will be conducted to both groups. The test contained twenty questions in 60 minutes. The students had to answer the questions based on the audio/audio-visual media which is delivered by the researcher as the teacher.

In order to get the result about significance differentiate from two independent variables to dependent variable, Two-ways ANOVA or two-dimensional analysis of variance technique was used since the independent variables are both audio-visual (A1) and audio (A2) teaching media, for the attribute variables are high (B1) and low (B2) motivation students, while dependent variable is students' listening achievement.

\section{FINDING AND DISCUSSION}

The data analysis in this research used Two-ways Analysis of Variance (ANOVA) thus the data should be in normal distribution and homogenous. The data description and the summary of calculation results by using Two-ways ANOVA can be seen in the Table 2. and Table 3. as follows:

Table 2. Summary of Data Description

\begin{tabular}{lcccccccc}
\hline \multicolumn{1}{c}{$\begin{array}{c}\text { Statistical } \\
\text { Values }\end{array}$} & A1 & A2 & B1 & B2 & A1B1 & A1B2 & A2B1 & A2B2 \\
\hline $\mathrm{N}$ & 50 & 50 & 50 & 50 & 24 & 26 & 24 & 26 \\
Sum & 4040 & 3870 & 4025 & 3885 & 2110 & 1930 & 1915 & 1955 \\
Highest Score & 100 & 100 & 100 & 90 & 100 & 90 & 100 & 90 \\
Lowest Score & 50 & 45 & 50 & 45 & 50 & 50 & 50 & 45 \\
Mean & 80.80 & 77.40 & 83.85 & 74.71 & 87.92 & 74.23 & 79.79 & 75.19 \\
Median & 80 & 77.50 & 85 & 76.25 & 90 & 77.5 & 80 & 75
\end{tabular}




\begin{tabular}{lcccccccc} 
Mode & 80 & 70 & 80 & 80 & 90 & 80 & 70 & 75 \\
Std Deviation & 12.79 & 11.53 & 11.85 & 10.46 & 11.22 & 10.55 & 12.47 & 10.34 \\
& & & & & & & & \\
\hline Variance & 163.63 & 132.90 & 140.65 & 109.2 & 125.9 & 111.38 & 155.39 & 106.96
\end{tabular}

Table 3. Summary of the Calculation Result of Two-Ways ANOVA Interaction between-Subjects Effects

\begin{tabular}{l|r|r|r|r|r}
$\begin{array}{l}\text { Dependent Variable: Listening Achievement } \\
\text { Type III Sum of } \\
\text { Squares }\end{array}$ & df & Mean Square & F & Sig. \\
\hline Source & $4555.247^{\mathrm{a}}$ & 3 & 1518.416 & 9.704 & .000 \\
\hline Corrected Model & 592062.245 & 1 & 592062.245 & 3783.963 & .000 \\
\hline Intercept & 1651.002 & 1 & 1651.002 & 10.552 & .002 \\
\hline Teaching_Media & 2679.245 & 1 & 2679.245 & 17.123 & .000 \\
\hline Motivation & 276.002 & 1 & 276.002 & 1.764 & .187 \\
\hline Teaching_Media * Motivation & 15020.753 & 96 & 156.466 & & \\
\hline Error & 609400.000 & 100 & & & \\
\hline Total & 19576.000 & 99 & & & \\
\hline Corrected Total & & & & & \\
\hline
\end{tabular}

a. R Squared $=.233$ (Adjusted R Squared $=.209$ )

The summary of two-ways ANOVA calculation in table above shows that $\mathrm{F}_{\text {observed }}$ value 1.764 and $F_{\text {table }}$ one 2.81, and result indicate the $F_{\text {observed }}<F_{\text {table }}$ while the significant value is 0.187 bigger than $\alpha=0.05$ or in other word $0.187>0.05$, this implies that there is interaction between Audio Visual Media, Audio Media and learning motivation toward the students' listening achievement. Based on the calculation results above, it can be seen that there is interaction among the dependent and independent variables in Figure 1. 


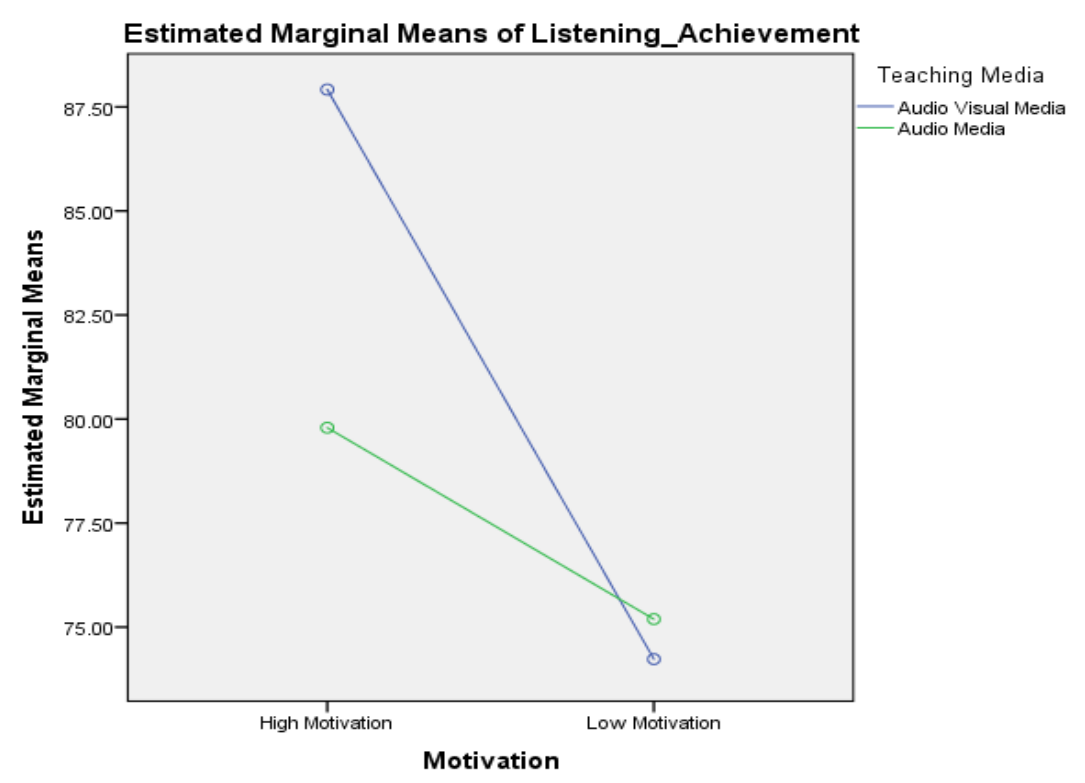

Figure 1. The Interaction of Teaching Media and Students' Motivation

From the figure above, the comparison between the line of High Motivation and Low Motivation shows the interaction pattern between audio-visual media, audio media and students' motivation. Students with low motivation will get significant results whether they taught with audio-visual media or audio media. The two lines have interaction, this can be seen from the line that crosses between the teaching media line and student learning motivation. The intersection from both two lines between the audio-visual media line and the audio media line shows that there are several students who have the same scores increased whether taught by using audio-visual media or by using audio media. The intersection of the two lines of audio visual and audio media shows that both of the two media have the same effect on improving student learning outcomes, in other words these students have an average improvement in student listening achievement.

The research findings showed that both audio-visual and audio media have significant interaction towards students' achievement in listening comprehension. It can be seen by the total mean both of teaching media, it shows that the students taught by using audio-visual media significantly higher than taught by using audio media. Both audio-visual and audio teaching media suitable with the students who have high motivation although audio media does not give maximum results like audio-visual media, audio media can be used to train students' sensitivity in learning process. In other words, students with high and low motivation will give better results if they treat with proper teaching media, in this case audiovisual and audio media. 
The result of two-ways ANOVA calculation indicates that there is significant effect of interaction between both teaching media and motivation on the students' listening achievement. The result of research findings revealed that both teaching media and students' motivation in learning are two important things which influence the students' listening achievement.

Broadly said, it can be concluded that the students who have high motivation in learning taught by using audio-visual media has better achievement in listening than taught by using audio media. They will get easily to understand the main idea of the text because they more interested and focus in watching the material given then imagine the whole part into real picture while they listening. Through cooperative process, students with low motivation will get easier to understand what the idea of the text is. Even so, the use of audio media in the learning process needs to be done in order to train students' sensitivity for improving their listening skills.

\section{CONCLUSIONS}

The variative teaching media is very important for students, it also occurs in teaching listening. Teacher should have an effort to implement many teaching media in order to improve the students' language abilities especially the students' listening comprehension achievement in descriptive text.

The summary of Two-ways ANOVA calculation indicated that $\mathrm{F}_{\text {observed }}>\mathrm{F}_{\text {table }}$ and it can be said that there is interaction between both dual teaching media and learning motivation to the students' listening achievement in this research. Thus, we can conclude that the dual teaching media and learning motivation have good impact on students' listening achievement.

\section{REFERENCES}

Anderson, A. and T. Lynch. (1998). Listening. Oxford: Oxford University Press.

Ary, D., Jacobs, L. Chester, C. Sorensen and A. Razavieh (2010). Introduction to Research in Education ( $8^{\text {th }}$ Eds.). California: Wadsworth.

Brophy, J. E. (2013). Motivating Students to Learn. Oxford, UK: Routledge.

Dornyei, Z. (2002). Motivational Strategies in the Language Classroom. Cambridge: Cambridge University Press.

Gilakjani, A. and N. Sabouri. (2016). Learners' Listening Comprehension Difficulties in English Language Learning: A Literature Review. English Language Teaching, 9(6), 123-132. 
Knapp, P. and M. Watkins. (2005). Genre, Text, and Grammar. Sidney: University of New South Wales.

Littlewood, W. T. (1998). Communicative Language Teaching: An Introduction. London: Cambridge University Press.

Mahadi, Y., Hanna and Haerun. (2018). The Effect of Multimedia on Students' Listening Comprehension at Eight Grade of SMPN 12 Kendari. Journal of Language Education dan Education Technology, 3(2), 1-15.

Miarso, Y. (2004). Menyemai Benih Teknologi Pendidikan. Jakarta: Prenada Media.

Murphy, D. (2003). You Can't Just Say It Louder. Huntington Beach: Sheel Education.

Nation and J. Newton. (2009). Teaching ESL/EFL Listening and Speaking. New York: Roudledge.

Nunan, D. (1999). Second Language Teaching and Learning. Boston: Heinle.

Pangaribuan, P., A. Sinaga. and K. T. Sipayung. (2017). The Effectiveness of Multimedia Application on Students Listening Comprehension. English Language Teaching, 10(12), 212-218.

Purdy, M. and D. Borisoff. (1997). Listening in Everyday Life: A Personal and Professional Approach, 2nd Eds. Lanham MD: University Press of America.

Rismawati. (2017). Teaching Listening by Using Authentic Videos. English Education Journal, 8(2), 222-233.

Rost, M. (2011). Teaching and Researching Listening. London: Pearson Education.

Sadiman, A. S. (2009). Media Pendidikan: Pengertian, Pengembangan dan Pemanfaatannya. Jakarta: Raja GrafindoPersada.

Ulum, O. Gökhan. (2015). Listening: The Ignored Skill in EFL Context. International Journal of Humanities Social Sciences and Education (IJHSSE), 2(5), 72-80.

Underwood, M. (1989). Teaching Listening. New York: Longman.

Wilson, J. J. (2008). How to Teach Listening. Essex: Pearson Education. 